\title{
Institutional Performers for Processing Infrastructure Reforms for SMEs
}

\author{
Najia Saqib ${ }^{1}$
}

\begin{abstract}
This paper is for developing countries such as Pakistan institutional performers (organizations, individuals) can exert individual agency in recalibrating state strategies for SMEs infrastructure provision. A second premise is that the successful outcome of such engagements is contingent on how performers through conscious efforts motivate peers and mobilize resources and competencies to facilitate experiments. The latter prescription dovetails into the terrain of "public-private partnerships" (PPP) that supposedly free the private sector from an omnipresent state thus enabling it to pursue competitiveness-based policies, which are the mainstay today of economic development everywhere. This paper's aim is to flesh out the role of institutional performers through a process-oriented mode of inquiry that underscores successful reform is underwritten by the distinctive institutional base of a region and the collective memory of its leader firms.
\end{abstract}

\section{JEL classification numbers: L32}

Keywords: Institutional performers, SMEs, public-private partnerships

\section{Introduction}

The starting premise of this paper is that in developing countries such as Pakistan institutional performers (organizations, individuals) can exert individual agency in recalibrating state strategies for SMEs ${ }^{\text {ee }}$ infrastructure provision. They do so by engaging different branches of the state in discursive experiments that involve an open-ended form of learning and can lead to new institutional architectures. A second premise is that the successful outcome of such engagements is contingent on how performers through conscious efforts motivate peers and mobilize resources and competencies to facilitate experiments. The role especially of local institutional performers matters considerably in efforts to upgrade infrastructure for industrial development. Conventional policy prescriptions for infrastructure reform rely, on one hand, on the classic supply-driven

\footnotetext{
${ }^{1}$ Assistant Professor, Prince Sultan University, Riyadh-Kingdom of Saudi Arabia.
} 
approach that reifies market reforms such as deregulation and privatization, and, on the other hand, on a demand-driven approach that seeks improvements in provision through governance decentralization. The latter prescription dovetails into the terrain of "publicprivate partnerships' (PPP) that supposedly free the private sector from an omnipresent state thus enabling it to pursue competitiveness-based policies, which are the mainstay today of economic development everywhere. This paper's aim is to flesh out the role of institutional performers through a process-oriented mode of inquiry that underscores successful reform is underwritten by the distinctive institutional base of a region and the collective memory of its leader firms. This observation resonates with a key point made implicit in an extensive body of work on the place of institutions and entrepreneurship in local and regional development (Sotarauta, 2005; Gertler, 2004; Lazonick, 2001; Whitley, 1999; Lane, 1997; Sabel, 1996; Nelson, 1993; Lundvall, 1992; Boyer, 1990).

Conventional infrastructure prescriptions then are shared by international agencies and policymakers alike regarding the purposeful redirection of resources and they tend to underplay the role of local knowledge and local institutional performers. Moreover, in traditional or supply driven ways of thinking about infrastructure provision for SMEs ${ }^{\text {ee }}$ industrial development, private performers play a negligible role in designing public solutions. Often they are viewed as free riders or presumed to have an interest in lobbying the state for their personal gain at the expense of the public. In developing countries such as Pakistan where SMEs contribute significantly to the economy ${ }^{2} 1$ and rely on ageing infrastructure, international agencies tend to presume that such resource starved and prostrate firms have no alternative but to remain passive recipients of market-led reforms where efficient resource allocation will lead axiomatically to desired outcomes (Anas et. al. 1996; ADB 2005; World Bank 2006a), or where private financing and risk mitigation through PPPs will ensure better service delivery . Since industrial policy in Pakistan continues to privilege large-scale manufacturing ${ }^{3}$, it is unlikely that a market-led approach for infrastructure provision can address sufficiently SMEs demands. Evidence (ADB 2005) suggests that firms in Pakistan contend with extensive infrastructure scarcities ${ }^{4}$ and depending on sector and institutional capacities these create a greater burden of adjustment on SMEs.

Recent research (Hausmann, Rodrik \& Sabel, 2007) on industrial policy in developing countries posits that market failures ${ }^{5}$ are a rampant feature of the landscape ee and this poses a challenge for traditional ways of thinking about designing interventions. Since public officials have limited ex ante knowledge about how, when, and where to provide specific public inputs such as infrastructure for private production, requisite interventions are bound to fail because state performers do not respond automatically to signals being

\footnotetext{
${ }^{2}$ In Pakistan SMEs contribute 30 percent in terms of value added, 80 percent of industrial employment, and hold a 25 percent share in manufactured exports. (GOP 2008, Pakistan Economic Survey 2008-2009. Islamabad: Ministry of Finance)

${ }^{3}$ Except for a brief interlude during the 1970 s when it was penalized under nationalization, largescale industry continues to enjoy state patronage. This bias is also emblematic of the state centric economic development paradigm that emerged in the fifties and sixties, e.g. Rostow, Gerschenkron, Scitovsky, Rosenstein-Rodan.

${ }^{4}$ Infrastructure scarcities include congested roads and drains, electricity blackouts, long transit time to sea ports, and unreliable route connectivity with suppliers.)

${ }^{5}$ The research asserts that three types of market failure - missing public inputs, coordination externalities, and self-discovery externalities - exist behind slow structural transformation hence slow growth in developing countries.
} 
generated. Similarly, private performers engaged within their sectors in a process of selfdiscovery intent on removing inefficiencies have a reservoir of practical knowledge ${ }^{6}$ but contend with extensive uncertainty. Hence, there is an overriding necessity for collaborative experiments between state officials and private performers to search for solutions. Moreover, as my case study will show, when state functionaries and private performers connect in local contexts opportunities emerge to learn novel approaches for identifying solutions that are often closer to development realities. Two questions arise then: what type of institutional arrangement facilitates connectivity between different layers of the state and private performers such as SMEs? Can collaborative experiments and an open-ended form of learning for infrastructure provision generate solutions that benefit districts and regions in the long run?

There is an extensive body of literature (Schmitz and Musyck, 1994; Schmitz, 1995; Schmitz \& Nadvi, 1999; Rabelloti, 1999; Gereffi and Bair, 2001) on SMEs industrial districts that refers to the ability of firms in developing countries to compete in global markets as enhanced significantly by the provision of suitable national infrastructure. Paradoxically it provides limited insight into how SMEs in developing countries can cope if, for instance, sophisticated transport logistics fail due to deteriorated ,hardware or poor quality roads and drains, congested air and rail transport, and overall poor maintenance and management of services, which is a widespread condition in countries such as Pakistan ${ }^{7}$. Even though scholars (Schmitz and Musyck, 1994) have underscored correctly the importance of local institutions in supporting industrial policy for SMEs, they have provided no guidance on how these can assist specifically in resolving infrastructure problems, especially for those firms located in landlocked regions where geography can exacerbate the problem of distance to foreign markets. Learning that generated not only new ideas but also led to the formation of a new institution - the City Package Association - which now constitutes a key connection between the state and private firms.

This paper makes an empirical contribution to the literature on industrial districts by showing how endogenous solutions based on the strength of local knowledge, informal processes and supportive institutions can facilitate $\mathrm{SMEs}^{\text {ee }}$ infrastructure upgrading for industrial development. In designing an industrial policy framework that is supportive of SMEs $^{\text {ee }}$ infrastructure demands in developing countries such as Pakistan, I make a case for the role of local institutional performers that organize effectively connectivity between firms and the state for generating innovative solutions that are closer to development realities. With the exception of one study (Gulyani, 2001) there are currently no empirical cases in the extensive literature on industrial districts and regional development that address explicitly the challenge of infrastructure upgrading for SMEs in developing countries. Virtually all empirical cases focus on the merits of technological upgrading and knowledge diffusion. I use a case from Sialkot, Pakistan to analyze how an informal process based on collective learning for problem solving developed and enabled SMEs and the state to improve inadequate infrastructure to enhance competitiveness.

The illustrative case I present here on Sialkot demonstrates that SMEs devised an innovative institutional arrangement to tailor infrastructure solutions to their needs. This

${ }^{6}$ I make here a distinction between ,practical knowledge ${ }^{\text {ee }}$ or tacit knowledge that is embedded in local experience and the formal abstract type deployed by international agencies.

${ }^{7}$ An exception is Gulyanies (2001) study on India. However, it does not address the issue of institutions.) 
arrangement was driven by a strong willingness to pay and manage that led to a firm-state experimental collaboration - the City Package project - for improving $30 \mathrm{~km}$ of local roads and eventually even for building an airport that could serve the region. The experiment generated positive spillovers for the entire industrial district. The case shows that such experiments can spawn positive outcomes for improving even roads, drains and for building airports that are understood in the canonical tradition as „lumpy infrastructure prone to the classic free rider problem. ${ }^{8}$

In the mid-1990s, Sialkot ${ }^{\text {ec }}$ main roads were in a disastrous state and SMEs, for instance in the sports goods sector ${ }^{9}$, confronted major challenges in maintaining good route connectivity with their local suppliers and in convincing foreign buyers to visit the industrial district. The response of firms from the sports goods and other sectors equally affected by the inadequate road conditions was an innovative solution for infrastructure upgrading. The strategy depended on experimentation and extensive collaboration between firms across diverse sectors and on initiating open-ended conversations with officials from different branches of the state to harness resources and monitor developments. The core process unfolded over a period of seven years (and is still ongoing) and in the context of a national economic policy regime that has been liberalizing the economy, and firms across Pakistan have been coming under new competitive pressures. The SME ${ }^{e c}$ in Sialkot are acutely aware of these changes and the contingencies involved for remaining competitive in global markets. While the process for developing improved alternatives was predicated on mobilizing resources for the City Package project, a greater challenge for the SMEs lay in developing a shared understanding of the need for a collaborative endeavour. In this context, proactive business associations provided a space for private performers from diverse industries and for senior state officials to engage in discursive interactions and to generate new frameworks of action to facilitate solutions. Before turning to an examination of the City Package experiment, I briefly discuss in the next section the accepted wisdom on economic development based on the role of learning and institutions rather than on the conventional or neoliberal view that focuses exclusively on the perfect market mechanism.

\section{Learning, Institutions and Regions}

The literature on institutions and learning in economic development provides valuable insights for understanding the micro-process of building state-SMEs relations for problem solving and the requisite institutional arrangements that have enabled firms in Sialkot to devise infrastructure solutions for their industrial district and the broader region. The role of institutions in economic life has been clarified by scholars such as Polanyi (1944) and further emphasized by others such as Gertler (2010, 2004). The key point in the literature is that institutions exert considerable influence on the evolutionary trajectory of regions and local economies. In a departure from the dominant neoliberal view (Balassa, 1988; Bhagwati et. al., 1984) that assumes firms respond automatically to price signals in

\footnotetext{
${ }^{8}$ Hirschman, A. (1958))

${ }^{9}$ Sialkotes s sports goods sector produces nearly 70 percent of the world"es soccer balls some selling on average for US \$100 each. In 2006, the value of merchandise exported from this sector was approximately US \$343 million.)
} 
competitive markets, the literature on learning contends that acquiring new skills are central to the process of economic development ${ }^{10}$.

But learning also encompasses the building of institutions or improving existing ones through a socially and politically interactive process (Gertler, 2010). In this context, the concept of „learning-by-monitoringee (Sabel, 1992, 1994) is useful for understanding an informal process that emerges when performers interact at multiple levels. Learning refers to a process that involves the production of both technical and organizational knowledge, and monitoring refers to arrangements between transacting parties to assess that each is getting a fair deal. Learning is understood as an uncertain, open-ended and socially and politically interactive process about which state functionaries and private performers have no prior knowledge about how things will change. In contrast to the state demanding performance from private firms and acting as the primary institution that induces learning (Amsden 1989, 2001), in Sabel "es approach private firms search for their own selfsustaining learning processes to create or strengthen institutions and to connect with the state. By helping reduce information asymmetries, the process revolves around the principles of goal setting, continuous re-evaluations, and assessments toward reaching a requisite end. It creates an opportunity for participants (firms, state officials, business associations) to reorient preferences toward developmental rather than rent-seeking goals. The process is also highly demanding and can be reconciled when private performers hold discussions in discursive institutions (Sabel 1994; Iskander, 2006). Discursive institutions are spaces where individuals can interact, where persons with different interests can meet to discuss problems, set goals and revise preferences. Such institutions open a space for dialogue and the possibility of challenging assumptions and generating new insights. When discursive interactions are successful, the organizations where these learning processes unfold become key connections between the state and the economy and between economic agents. In the specific context of understanding state-SME relations that can generate innovative and contextualized solutions for infrastructure upgrading, I argue that state and non-state performers in developing countries such as Pakistan can through collective learning strengthen institutions that make solutions possible. Moreover, when public officials and SMEs establish connections that are goal oriented, these can lead to new possibilities and enable the forging of new partnerships and the building of new institutions to support ongoing challenges for SMEs ${ }^{\text {ee }}$ industrial development.

The effectiveness of new knowledge to be generated and shared between firms and the state depends on the extent that principles of learning-by-monitoring emerge during the interactive process between private performers and between the state and private performers. As this case study suggests, collective learning and searching for infrastructure solutions is an open-ended and disruptive process but the state plays a significant role by establishing a connection early on and most critically under those conditions where such connectivity has been historically weak, as this had been the case for the SMEs in Sialkot. The next section discusses how reform efforts entailed a process of constructing institutional arrangements and reorganizing relations between private performers, state officials, state agencies and business associations.

\footnotetext{
${ }^{10}$ Development theory has moved away from a focus on processes of accumulation and mechanization to a focus on processes of learning and organizational change (Amsden 1989, 2001). Center-stage in this perspective is the role of institutions as a key to fostering growth.
} 


\section{Facing the Challenge of Ageing Infrastructure}

With a population of 3 million, the district of Sialkot lies in the north-eastern region of Punjab, Pakistan, close to the Indian Jammu-Kashmir border. The district lies over 3000 $\mathrm{km}$ from the sea port of Karachi and, until recently, was nearly three hours by road from the nearest international airport. After Karachi, Sialkot is considered Pakistan "es second largest source of foreign exchange earnings generated mainly through its SME dominated export-oriented industries. Even though Sialkot is well-known for its SME industries, such as the surgical instruments, sports goods and leather goods clusters ${ }^{11}$, and these have for decades been producing merchandise almost exclusively for foreign markets, the region has only managed recently to acquire an international airport. The state $s$

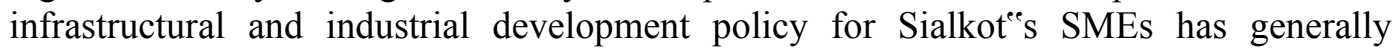
gravitated toward „benign neglecte, an attitude attributable to the state-centric and largescale manufacturing driven industrialization model that emerged in the after-math of independence from British rule in 1947.

In the mid-1990s scholars (Ghani, 1996:11) had observed that Sialkot's SME industries confronted a growing challenge due to ageing infrastructure: „Infrastructure facilities are woefully inadequate. This includes poor air, road and rail transport....the drainage is in shambles." Similarly, another scholar had asserted (Nadvi, 1999:99) that Sialkot was „plagued with bad roads....in these areas of common need, collective mobilization of resources could ease cluster-wide constraints. Yet, signs of local producers seeking a collective resolution to these problems are rare....Collective action to meet common needs fails due to fears of free riders." Road construction in the Sialkot district has been handled historically by the provincial government, for instance the Public Health and Engineering Department (PHED). ${ }^{12}$ Typically the PHED built the local roads and drains and handed operations and maintenance (O\&M) over to the local Tehsil Municipal Association (TMA). This supply-driven approach has been criticized for its failure to establish ownership in the O\&M of district roads, an issue that the SMEs in Sialkot have tried to continually address with local branches of the state.

In the province of Punjab the central government's spending on the O\&M of physical infrastructure fell from 17 per cent of total expenditure in 1998 to just 11 per cent in 2001, and resource allocations for the O\&M of provincial roads became the lowest (ADB, 2003). The gradual shrinking of infrastructure-related funds had a clear impact especially on secondary cities such as Sialkot where ageing infrastructure posed myriad challenges. The problem of shrinking funds for infrastructure development is emblematic of the inherent bias toward larger cities such as Lahore and Faisalabad that tend to command the lion ${ }^{\text {ee }}$ s share of provincial funds. In the words of a well-respected Sialkot entrepreneur who is actively involved in the City Package Project:

Even with Shahbaz Sharif who is Chief Minister of Punjab for a second time these days, the maximum money spent is on cities like Lahore. If Rs. 200 million is spent on a road development project then 180 million of that will go to Lahore and the remaining 20 million will be given to smaller cities. Big cities take up the lion ${ }^{\text {ee }}$ share because these are considered important politically. This even happened during General Musharrafes regime. There is no doubt smaller cities like Sialkot have developed in the last fifteen years, but

\footnotetext{
${ }^{11}$ Cluster define as sectoral and geographical concentration of firms and „industrial districtee as horizontal linkages between firms.

${ }^{12}$ This is the case for all districts in Pakistan
} 
still most of the money for infrastructure has gone toward big cities. Our region is always last on the list. (Interview: December 2009)

In the nineties in Sialkot the O\&M of roads had become inadequate in terms of keeping up with normal deterioration due to the impact of overloaded vehicles, unexpectedly high traffic volumes, increased flow of effluent into the main drains, and damage from seasonal rainfall (Punjab experiences intense rainfall during the annual monsoon season). The road deterioration was causing frequent and extensive flooding and the impact on the SMEs, which are located in industrial estates accessed from the main roads, was significant:

Sialkotes main roads were in a disastrous state. We had serious problems with sewage and flooding. At times the roads were constantly engulfed in knee-deep water. This would last for weeks. There were days when we could not access our fperformeries or even drive on the roads. Our subcontrperformers could not access the main roads leading to the fperformeries. Worst of all, the impression the roads created on our foreign buyers was terrible. They did not want to visit our fperformeries. Poorly maintained roads were undermining our economic survival. (Interview: March 2006)

The opinion of this leading sports goods manufacturer resonates with the views expressed by managers in this and other sectors as well. A central concern for the firms was the problem of late deliveries from local suppliers due to inaccessible road conditions and the perceptions of their foreign buyers who were unwilling to visit Sialkot. In 1998 the SMEs began strategizing how to mitigate the burden. The initial conversations began informally amongst a small group of SME representatives who were based in the district-wide business association, the Sialkot Chamber of Commerce and Industry (SCCI). The SCCI soon emerged as a key institutional mechanism connecting the SMEs with key state officials.

\section{Connecting and Collaborating}

In 2006 in Pakistan a new category of service was added to the extensive discussions on the declining state of public infrastructure. The stories that dominated were not focused on ,electricity blackoutse but on the monsoon rains that had brought the country ${ }^{\text {ee }}$ most important industrial center and key port - Karachi - to a virtual halt by flooding and destroying the citye's road system. The effect of the crisis on Karachiees industry was immediate. Firms in industrial estates could not receive inputs from suppliers or deliver merchandise to foreign customers as major road links to the airport and seaports had collapsed. The scene of everyday life ,up north ${ }^{\text {ee }}$ in Sialkot belied Karachiees deteriorating landscape. Despite a particularly heavy monsoon season, the main roads in the city were bone dry facilitating the flow of traffic. It is paradoxical that a diminutive secondary city and landlocked and neglected industrial region should succeed in overcoming infrastructure constraints whereas a large economic center collapsed under the weight of poor quality roads and drains. In 1999, the SMEs in Sialkot were also contending with extensive road problems. However, something unique happened. A small group of individuals representing a cross-section of industries began discussions about whether or not to take the responsibility of improving bad roads and blocked drains or whether to wait for the state to do it.

Given the government's history of negligent infrastructure policy towards Sialkot's SMEs and the district government's weak resource base the choice for the firms was simple: 
„We knew the only way to engage the government was to take the first step and raise the finances to improve the roads. Otherwise our businesses would have continued suffering." (Interview: March, 2006) The discussions between private firms unfolded in various discursive institutions ranging from the sector specific business associations and districtwide Sialkot Chamber of Commerce \& Industry (SCCI), and eventually led to the formation of a new association - the City Package Association (CPA) - that continues to search for novel solutions for ongoing infrastructure problems. In devising a strategy the firms also engaged the state in a way that calls into question the assertion that Pakistani public officials are complacent and business organizations are rent-seeking. The firms ${ }^{\text {ee }}$ strategy challenged the state ${ }^{\text {ee }}$ s historical policy of benign neglect of Sialkot te $^{\text {te }}$ SMEs. In doing so, they compelled the state to invest in additional infrastructure services, such as a dual carriageway and an international airport that linked eventually Sialkot ${ }^{\mathrm{te}} \mathrm{s}$ industrial district and the broader region of north-eastern Punjab to national and global corridors of economic activity. The strategy the firms devised depended heavily on collaborating both with each other and with the state, leveraging business associations, organizing and deploying financial resources and finding ways to improve the arteries of their enterprise. The success of the City Package project was predicated on a form of collaboration in which business organizations became the central force for conversations among firms from different sectors and for connecting firms with public officials who represented different layers of the state. A representational diagram of the institutional performers and their connectivity is presented below in Figure 1. The arrows indicate a two-way flow of information between different institutional performers and organizations. The different shapes represent state (blue) and non-state performers (olive) who collaborated. The red circle denotes the new institution that was created, the City Package Association, and the performers and organizations that currently comprise its core. 


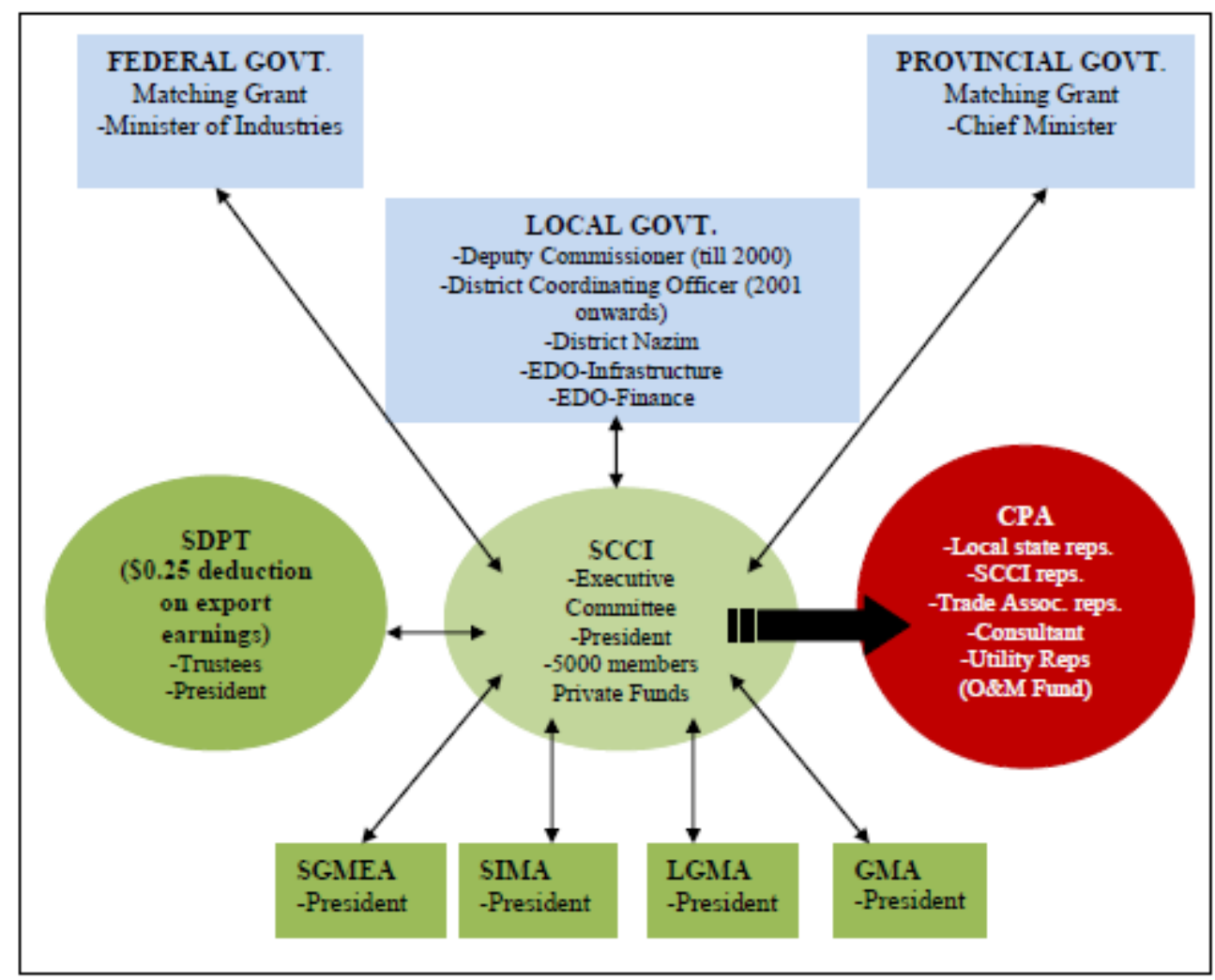

Figure 1: Institutional performers and organizations in the CPP

The conversations held in the SCCI had gradually led to the recognition that a key problem could not be solved without mutual collaboration. As collaboration grew trust became implicit obviating the need for parties to check in with each other every day. The collaboration also led to the creation of the CPA whose role local government has recognized as an important one. Above all, the SMEs have learnt that as active stakeholders in the project they have the capacity to influence the trajectory of local economic and regional development. An opportunity for the firms to find a solution to deteriorating road conditions arrived in 1997 when the provincial government launched the Big City Development Package to upgrade infrastructure in eight secondary cities including Sialkot in north-eastern Punjab. Its arrival was timely because it gave the Sialkot firms an opportunity to unveil before the state their own plan for the industrial district.

The provincial government's project was launched in 1997 but in Sialkot the pace of road upgrading was deemed slow. Resource constraints were impeding further improvements and the private firms believed additional roads required immediate attention as upgrading them would facilitate industrial and commercial activities, especially to improve route connectivity with subcontrperformers and enable foreign buyers to visit the city. Between September 1998 and February 1999, the Sialkot Chamber of Commerce \& Industry (SCCI), which has district-wide membership spread across 5000 firms representing diverse industries, became the primary organization for holding discussions to consider possible approaches for expediting road improvements. Initially, the conversations were limited to a small group (approximately twenty individuals) that included the president of 
the SCCI, the executive committee and senior representatives of the sector-specific business organizations. These individuals were owners and managers of venerated leader firms from diverse industries. Several had participated actively in earlier successful efforts to improve Sialkot's infrastructure for instance the establishment in the eighties of the Sialkot dry port trust (SDPT). When the initial conversations about financing road improvements began in 1997, a senior representative in the group also happened to be the president of the SDPT. In essence, the collective memory of these individuals attested to the possibility of generating a successful outcome through collaborative means. Moreover, the representatives of the leader firms consciously chose to shoulder the responsibility of mobilizing their peers and public officials into conversations that would recalibrate eventually the state's role. Through their respective social networks and influence based on venerable reputations the leader firms assisted in the widespread diffusion of the plan's necessity and its anticipated positive outcome.

The small group agreed to mobilize private funds to set up an independent City Package project that could be managed and monitored by the Executive Committee of the SCCI. However, the plan ran immediately into obstacles. The SCCI approached the Federal Board of Revenue (FBR), which operates under the Ministry of Finance's ambit to request assistance for earmarking a portion of Sialkot's export earnings toward a special fund for road improvements. But the FBR could not take a unilateral decision without the approval of the Ministry of Finance. In 1999 the SCCI invited two senior state functionaries - federal level Minister of Industries and the provincial level Chief Minister - to discuss the growth of Sialkot's industries. Under the second Nawaz Sharif government (1997 - 1999) export-led growth was considered vital to the state's industrial development strategy. The senior state officials ${ }^{\text {ee }}$ visit to Sialkot was aligned with the general interest to promote export-led industrialization, a step that was part of a larger strategy to gradually liberalize the nation's economy. In the discussions the firms highlighted the conditions of the deteriorating roads and drains and voiced their idea for financing the road improvements. Their objective was to convince the senior state officials to influence the federal agency or FBR.

The discussions produced an unexpected development. Influencing FBR was not an option but the officials averred that if the firms managed successfully to mobilize private funds, the provincial and federal governments would then provide matching grants at three times the value. The private performers now had to strategize not only to mobilize funds but also to convince peers from diverse industries and local state officials to participate. They had to do this even though they could not be fully certain of the senior state officialse pledge actually materializing. The approach the small group of firms applied in searching for solutions was highly experimental. They had no advance blueprint on how to go about mobilizing private funds, securing the government's pledge, and rebuilding roads and drains. By holding discussions in the SCCI and in other business associations the firms had opportunities to develop and test ideas and plans. While some failed, other more innovative possibilities emerged.

Since the FBR plan for funding road improvements had failed the SCCI in conjunction with the presidents of the sector-specific business associations ${ }^{13}$ approached the Sialkot

\footnotetext{
${ }^{13}$ The sector-specific business associations were the Sports Goods Manufacturers \& Exporters Association (SGMEA), Surgical Instruments Manufacturers Association (SIMA), Leather Goods Manufacturers \& Exporters Association (LGMEA), and Garment Manufacturers Association (GMA))
} 
Dry Port Trust (SDPT) to organize a deduction on export earnings, specifically to deduct US $\$ 0.25$ on every US $\$ 100$ worth of merchandise that was shipped by the exporters. But getting the SDPT to participate could not be taken for granted. The SDPT ${ }^{\mathrm{ee}} \mathrm{s}$ thirty seven trustees had to act unanimously to approve the plan and even though a majority ultimately supported the deduction, the ones who opposed the plan were firms who believed that road improvements were a state responsibility. The dissenting voices belonged to large firms from the sports goods and surgical instruments sectors. In the mid-1990s several large firms had relocated outside the industrial district in areas where the unreliable road conditions did not directly affect them. They cited their taxes already financed the provincial and local government's operations for building roads and drains in Sialkot. Another perspective on the opposition is that the US \$0.25 deduction on export earnings would have placed a higher burden on large firms because of the value of consignment booked through the SDPT. Consequently, these firms had protested the most because they envisaged their absolute contribution being greater. After extensive discussions that lasted several months, a plan was eventually devised to classify the deduction as "voluntary " rather than a compulsory tax on export earnings. Although most of the SCCI members responded positively to the plan there were many who had resisted. In those instances where firms had resisted the president of the SCCI along with representatives of the leader firms made informal visits to the owner of each firm and one by one drew them into a productive dialogue. By using their social network and influence the leader firms convinced their peers of the strategy. According to a former president of the SCCI the process was time-consuming but highly effective. The SCCI ${ }^{\text {ee }}$ s and leader firms ${ }^{\text {ee }}$ collective efforts to convince peers to join in the voluntary deduction scheme continued unabated despite the changes that unfolded in the organization's leadership structure between 1999 and 2007. These critical interactions straddled both the social and professional domains and proved to be effective in solidifying links between the representatives of the leader firms and those who were recalcitrant. The eventual positive response demonstrated the shared incentive across diverse industries to find a solution. The extensive response ultimately enabled the small team of individuals in the SCCI to extend its reach to local government and launch, in late 1999, a more coordinated strategy in collaboration with the head of local government, the Deputy Commissioner (DC).

Until the Federal Government's devolution plan15, the DC had been the highest ranking civil servant in the district administration with a direct reporting line to the unelected provincial secretariat. Without the DCees participation the firms would have had difficulties working with public agencies. By drawing the DC into the partnership, the SCCI achieved three objectives: (1) it signed a MOU with the DC enabling local government to become a stakeholder in the project, which proved valuable for handling eminent domain; (2) appointed the DC as a cosignatory for operating a bank account where private and public funds were deposited, thereby strengthening accountability in dispersing funds; and (3) identified a legitimate way of providing both the provincial and federal levels of the state the necessary evidence to secure the pledged funds. The DC played an active role in meetings held at the SCCI and especially at the sector specific trade associations where he endeavoured to convince representatives to maintain the voluntary contributions. By first quarter 2000, the firms had raised US \$1.7 million through their export earnings. By year end 2004, the provincial and federal governments had also delivered on their promises. The government funds were secured without using political clout or by making announcements in the media. By 2007 nearly $30 \mathrm{~km}$ of roads within the city had been upgraded. From Figure 2 it can be gleaned that the total cost of 
the project inclusive of private and public contributions was approximately US \$10 million. The private sector's share in financing the project was approximately 30 per cent while the remaining share was spread across the municipal, provincial and the federal governments with the provincial level holding the higher share in the category of public sector contributions.

\begin{tabular}{llcl}
\hline Stakeholders & Source of Funds & Resources Committed & Share \\
Provincial & Big City Package & US \$3.3 M & $34 \%$ \\
Provincial \& Fed & Matching Grant & US \$2.5M & $26 \%$ \\
Municipal & Sale of TMC Assets & US \$0.9M & $9 \%$ \\
Private Firms & Export Earnings & US \$2.9 M & $30 \%$ \\
Other & Miscellaneous & US \$0.2M & $1 \%$ \\
\hline TOTAL & & US \$10M & $100 \%$ \\
\hline
\end{tabular}

(Source: Ace Consultants (Pvt.) Limited, Sialkot, Pakistan, May 2006)

Figure 2: Financing the City Package Project - Public \& Private Shares

The provincial government had not only contributed resources to the City Package project but it had also put a price-cap on the contrperformer's fee by locking it in for a period of five years to curb the costs of construction for the Sialkot firms. At year end 2005, when the first phase of the project was completed, the market rate for materials for road construction had escalated by nearly 60 per cent. For instance, the consultant/engineer explained that the cost of steel and cement had escalated significantly since 2005. While the mobilization of private and public funds was an impressive achievement a greater challenge lay in establishing the institutional arrangements to coordinate and ensure continuity. At the initial stage, the city-wide SCCI had formed an informal in-house committee to hold discussions and exchange ideas. However, it soon became apparent that the size and scale of the project demanded an independent association that could coordinate the multiple objectives of private firms, bureaucrats, consultants, and contrperformer's. An informal committee did not have the know-how to coordinate and implement road improvements. Since the role of local government was now central to the plan, it underscored the need for a formal association that was not only physically connected with the DC ${ }^{\text {ee }}$ s office but which could also take advantage of the office's expertise, for instance to solve eminent domain problems.

The committee was relocated to the DC $\mathrm{DC}^{\mathrm{s}}$ office where it assumed a more formal role of an association - the City Package Association (CPA) - with an appointed chairperson and representatives from the sector-specific business organizations and local government agencies, such as the EDO-Infrastructure. The CPA ${ }^{c e}$ main objectives were (1) coordinating and monitoring logistics of road improvements plans and (2) enabling productive dialogue and resolution of conflicts. But eventually the CPA ${ }^{\text {ee }}$ s role extended beyond its original capabilities by creating opportunities for both local state officials and private firms to consider new ways to improve infrastructure services. The CPA has 
managed numerous activities which have included engaging an independent private engineering consultant; an intelligent move encouraged by the SCCI ${ }^{\text {ee }}$ Executive Committee. The consultant was answerable to the private firms and closely monitored the contrperformer's performance. More importantly, the consultant ensured the installation of drains preceded the road improvements, an objective the firms had prioritized. A critical concern for the association's representatives was to generate feedback about the project to firms across different sectors. As the project progressed fewer members from the private sector attended weekly meetings on a regular basis. The sector-specific business organization and the city-wide SCCI were kept updated by the CPA through monthly progress reports and the association's ledgers and account books could also be easily accessed.

But collaboration did not always deter the likelihood of conflict. In 2002 General Parvaiz Musharaff's devolution plan brought about a new system of governance at the local level with the role of the DC being abolished and the District Coordinating Officer (DCO) emerging as the district's high-ranking civil servant along with the elected representatives, the mayor or nazim. The changes in local governance structures added a new constellation of performers to the $\mathrm{CPA}^{\text {ec }} \mathrm{s}$ membership. Although the mayor has been viewed as a facilitator, in certain cases his involvement also created obstacles. For instance, on the eve of local elections in 2004 clearing encroachments along one road became controversial thus creating a potential deadlock in the CPA. In this instance, the firms had to relent and find an alternate route. The encroachments were a challenge that the DC and later the DCO helped resolve:

A key objective in the project was to install new drains especially storm drains before rehabilitating roads. This was an objective shared by all parties. They understood this small but critical detail would eventually determine the success of the project, specifically in terms of keeping down the recurrent costs of maintenance and road closings. Since 1999 approximately $30 \mathrm{~km}$ of local roads and ancillary drains have been successfully upgraded and another $20 \mathrm{~km}$ have been targeted for rehabilitation. The most outstanding and visible achievement is the elimination of flooding and sewage spill over especially along the main routes leading into and within the industrial estates. With widened footpaths, pedestrian traffic is now set back from the main roads as are the local shops, which has improved road safety and the flow of traffic. For the firms, their subcontrperformers travel time to and from fperformeries has improved with better route connectivity and easier access to the industrial estates. The achievements have also enabled the firms to persuade their foreign buyers to visit Sialkot more frequently. A benchmark for evaluating the success of the project is to compare it with the Lahore Road Rehabilitation Project (LRRP) project which was also implemented in 1999. Since 2000, several roads completed under the LRRP project were resurfaced at least once. In contrast, the City Package roads completed in the same year have not required resurfacing thus far. Under both projects roads were designed to ten years ${ }^{\text {ee }}$ service life that is the minimum standard for a road's life expectancy in a donor-funded project (ADB, 2003). The discrepancy in the LRRP project has been attributed to the installation of weak drainage structures.

The City Package Association (CPA) that emerged from the highly interactive process of searching and collective learning has continued to collaborate with local state officials, private firms, and with representatives of other key organizations. Figure 3 below illustrates the connectivity and the CPA ${ }^{\text {ee }}$ s key position in the matrix of relationships. 


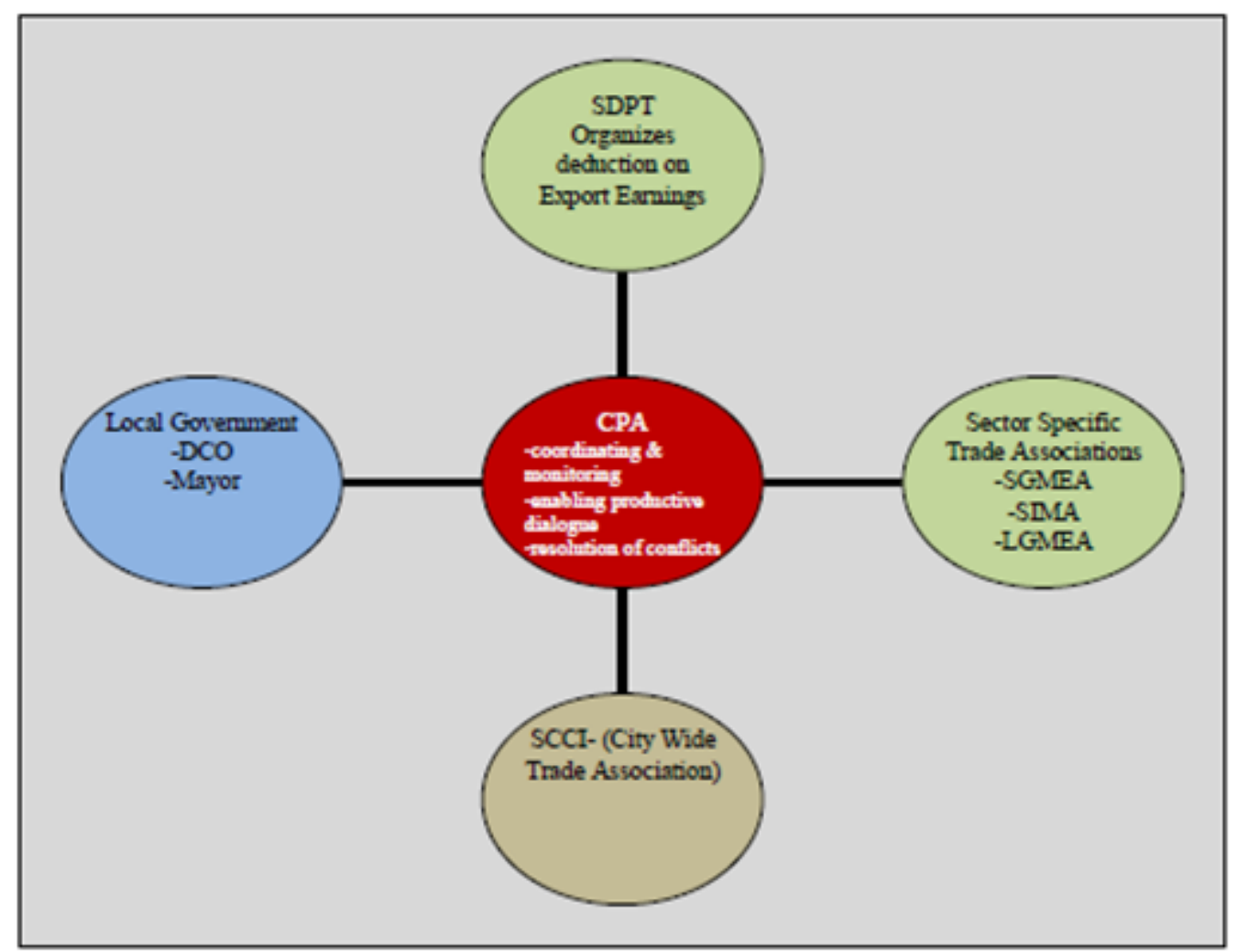

Figure 3: City Package Association \& its connectivity with key organizations

One of the CPA ${ }^{\text {es }}$ on-going tasks is to find new ways of mitigating O\&M problems and to mobilize further capital to upgrade additional roads. An interesting aspect of surmounting the O\&M challenge - an Achilles heel of infrastructure - is the way representatives of private firms learned to monitor road improvements. The current Chairman, a sports goods manufacturer, of the CPA explains thus: Over the years we have learnt that in upgrading roads the first thing is to sort out the services, e.g. lying down of electricity lines, water pipes, phone lines, fibre-optic cables. The roads have been constructed with our hard work and contribution of private funds. When a service agency starts digging a road it feels as if our hearts too are being dug. When services are shifted along a particular road so many hurdles arise because different commands emerge from different head offices and roads are broken again and again. This costs a great deal of money in the upkeep of a road. We have learnt through our experiences and have convinced the nazim, engineers, service providers, and the DCO that to prevent roads from being broken repeatedly, it is better to try to find an alternate approach. So for instance with Wateen and World Call who lay cables they agreed to install cables by attaching them to the roof of drains rather than by breaking up roads. We also asked them that since they now earn revenue so what will they contribute to this city. We asked for a donation which we got. With the money donated we have created a fund for on-going maintenance and repairs of roads. This O\&R fund is managed by the CPA. (Interview: December 2009)

The road improvements resulted in benefits not only for the firms, their suppliers, foreign buyers, and local government, but also for the shopkeepers located on the upgraded roads. The shopkeepers had become a hindrance for the firms by creating the classic "free rider" 
problem. ${ }^{14}$ The CPA asserted the problem could be tackled only by engaging shopkeepers into becoming stakeholders in the road improvements. The association had managed to draw some shopkeepers into weekly meetings to discuss strategies for the long-term maintenance of roads and drains. A discussion concerned putting together a map showing disposal points for plastic and other solid waste from the shops to the main areas where the Tehsil Municipal Association (TMA) vans pick up the waste. The successful implementation of such plans is predicated on how far-reaching the effects of devolution will be at the district and sub-district level in Sialkot, and to what extent the firms can influence the District Coordinating Officer (DCO) and the mayor to prioritize delivery.

\section{Conclusions and Policy Implications}

This paper has argued that conventional policy wisdom concerning infrastructure provision in developing countries underestimates the role local institutional performer's play in facilitating SMEs demands. Moreover, conventional policy wisdom does not acknowledge the subtle impact such institutional agency has on a local economy's and region's development. Policymakers and international agencies tend to view SMEs as prostrate and resource-starved firms with no alternative but to wait for requisite reforms. In this view private economic agents play no role in designing public solutions and this type of thinking gives short shrift to the role local institutions play in enhancing firm-state connectivity for identifying and facilitating solutions that are often closer to development realities. This is significant for addressing SMEs infrastructure needs generally sidelined in developing countries such as Pakistan where the policy environment is partial to large firms. In this context, the role institutional performers ${ }^{\text {ee }}$ play in strengthening state-SME relations is indispensable for designing government interventions. As this case study has shown the demand for reliable roads in Sialkot engendered extensive debates between firms and business associations for engaging the state at multiple levels. In 1999, a small constellation of institutional performers catalyzed conversations concerning road improvements.

These conversations are still ongoing and have evolved despite several regime changes at the national level and governance reforms at the local level. In 1999 the SCCI brought a small group of individuals and senior state officials together in a way that the SMEs on their own could not have done as they lacked the requisite „muscle power"e of a large firm. It provided an interactive space for discussing approaches and for facilitating informal dialogue to propose new ways of searching for innovative solutions. From this perspective the SCCI assumed a developmental role that is a departure from the conventional profile of a rent-seeking business association. But the process that led to a developmental outcome was predicated on shared interests between non-state performers and state officials who were willing to consider new approaches.

The examination of the informal micro-process that led to the success of the City Package project also shows public officials were committed and problem solving. This underscores the weakness in the dominant neoliberal view that sees merit in reducing the role of the state. While arguments for privatisation and deregulation are important, they miss out a key dynamic in that without supportive institutional structures infrastructure reforms are bound to fail. This case study highlights the social returns that accrue when public

\footnotetext{
${ }^{14}$ Shopkeepers were criticized for throwing plastic waste that led to blocked drains.
} 
officials and local economic agents connect and search for new ways of learning for infrastructure provision. Such collaborations for overcoming deficits are embedded in the strength of local knowledge, local institutions, and informal practices. This perspective departs from the conventional approach international agencies, having derived it from North $(1990,2000)$, hold that institutions are rules of the game at the national or macro level, for instance, property rights, judicial systems, regulatory frameworks and constitutions. The conventional view posits failure in the macro-institutional framework automatically impedes a country's economic development.

This case study suggests that local institutions (organizations and performers) are equally important because state functionaries and private agents often engage in open-ended and discursive experiments that can lead to the strengthening of old institutions and even toward creating new ones. This process has a direct effect on enhancing infrastructure provision for SMEs industrial development. The results in this case offer reflections for international agencies and policy makers on the role of local institutions and the importance of collective learning in assisting infrastructure improvements for SMEs upgrading. The research also suggests that practical knowledge plays a key role in building capability through continuous revisions and deliberations for joint goal-setting. From a policy perspective, especially as it pertains to current challenges of devolution/decentralization and the provision of infrastructure for SMEs in Pakistan, the principles of learning-by-monitoring can generate opportunities for the creation of new institutional arrangements that facilitate SME industrial upgrading. Future research on the role of institutions and learning in infrastructure reform for SMEs in developing countries should remain cognizant of how institutional performers interact, constrain and enable processes of transformation for industrial development.

Above all, this case highlights a critical point: forging partnerships is not a facile or guaranteed outcome. At a minimum, it is a process involving continuous revisions, strong leadership and conscious action which altogether endeavour to boost a local economy's and a region's infrastructure endowments for strengthening economic performance. As policy makers in developing countries shore up public-private partnerships and the market mechanism as „best practice ${ }^{\text {ee }}$ for designing infrastructure solutions to make local economies and regions competitive, a key lesson then that emerges from this case study underscores the centrality of productive dialogue between institutional performers (state and non-state) and distinctive institutional leadership as dynamics that continually reshape the process of reform. Put differently, infrastructure provision for SMEs ${ }^{\text {ee }}$ industrial development is a process embedded in place-based institutional structures and the successful outcome of this process is predicated on leadership capacity where performers (individuals, organizations, teams) have the power to mobilize resources, influence peers and recalibrate state strategies. A key question that emerges for future research is: can we comprehend leader firms as "rule-makerse whose collective memory is a regional endowment that underwrites leadership capacity? Streeck \& Thelen (2005) provide some clues on how to best approach this significant issue for regional development. In returning to the literature on SME industrial districts, I have argued in this paper that industrial upgrading is predicated not only on better managerial skills and knowledge diffusion, but also on applying creative strategies for infrastructure provision that give firms the ability to control the direction of their development. This resonates with earlier research (Gulyani, 2001) on firm-led infrastructure innovations that often deliver faster alternatives for managing and financing infrastructure for industrial growth. While not a panacea such 
alternative approaches embedded in place-based institutional architectures should be properly valued and understood alongside dominant or conventional ones.

\section{References}

[1] Amsden, Alice Asia's Next Giant: South Korea and Late Industrialization. Oxford: Oxford University Press. (1989)

[2] Amsden, Alice The Rise of the Rest: Challenges to the West from LateIndustrializing Economies. New York: Oxford University Press. (2001).

[3] Anas, A. et. al. Infrastructure Bottlenecks, Private Provision, and Industrial Productivity: A Study of Indonesian and Thai cities. Policy Research Working Paper No. 1603, The World Bank, Operations Evaluation Department, Infrastructure and Energy Division, May. (1996)

[4] Asian Development Bank, Report and recommendation on proposed program cluster of loans to the Islamic Republic of Pakistan for the Punjab resource management program $^{e}$.(2003)

[5] Asian Development Bank, SME Development in Pakistan: Analyzing the Constraints to Growth. ADB: (2005) WP. No 3.

[6] Asian Development Bank, Sector Assistance Program evaluation for the Road Sector in Pakistan. ADB: Operations Evaluation Department, (2006).

[7] Balassa, B., Outward orientation. H. Chenery and T.N. Srinivasen (eds.), The Handbook of Development Economics, V. 2, 1646-1689. Amsterdam, New York: North Holland. (1988)

[8] Bhagwati, J., et.al. DUP activities and Economic Theoryee. D. C. Colander (ed.), Neoclassical Political Economy: The Analysis of Rent-Seeking and DUP Activities, 17-32.Cambridge, MA: Ballinger Publishing Company. (1984)

[9] Gereffi, G. and J. Bair, Local Clusters in Global chains: The Causes and Consequences of Export Dynamism in Torreon "es Blue Jean Industry"e, World Development, 29, (11), 1885-1903. (2001)

[10] Ghani, J. A., Sialkot's Entrepreneurial Spirit. Center for Management and Economic Research, Lahore University of Management Sciences. (1996)

[11] Gertler, M Manufacturing Culture: The Institutional Geography of Industrial Practice. Oxford University Press, Oxford. (2004)

[12] "Rules of the Game: The Place of institutions in regional economic change", Regional Studies, V. 44 (1). (2010).

[13] Government of Pakistan (GOP). Pakistan Economic Survey 2008-09. Islamabad: Ministry of Finance. (2008)

[14] Gulyani, S.. Innovating with Infrastructure: The Automobile Industry in India. New York: Palgrave. (2001)

[15] Hausmann, R., D. Rodrik, and C. F. Sabel Reconfiguring Industrial Policy: A Framework with an Application to South Africa, August 31st, (2007).

[16] Hirschman, A. The Strategy of Economic Development. New Haven, Yale University Press. (1958)

[17] Iskander, N., Innovating government: Migration, Development and the State in Morocco and Mexico 1963-2005. Ph.D. Dissertation, Massachusetts Institute of Technology (MIT), Boston. (2006) 
[18] Nadvi, Khalid „The Cutting Edge: Collective Efficiency and International Competitiveness in Pakistan "e, Oxford Development Studies, 27 (1) 81-107. (1999)

[19] North, Douglas. Institutions, Institutional Change, and Economic Performance. New York: Cambridge University Press. (1990)

[20] North, Douglas,, Big-Bang Transformations of Economic Systems: An Introductory Note, Journal of Institutional and Theoretical Economics 156 (1) 3-8. (2000)

[21] Polanyi, K. The Great Transformation (1944)

[22] Rabellotti, R., Recovery of a Mexican cluster: Devolution Bonanza or Collective Efficiency?, World Development, (1999) 27, (9), 1571-1585.

[23] Sabel, C. F., Learning by Monitoring: The Institutions of Economic Development (1994)

[24] Smelser and R. Swedberg (eds.) The Handbook of Economic Sociology, 137-165. Princeton,

[25] NJ: Princeton University Press.

[26] Sabel, C. F, Studied Trust: Building New Forms of Cooperation in a Volatile Economy .(1992)

[27] F. Pyke and W. Sengenberger (eds.), Industrial Districts and Local Economic Regeneration. Geneva: International Institute for Labor Studies, ILO.

[28] Schmitz, H. „Small Shoemakers and Fordist Giants: Tale of a Superclustere, World Development, (1995) 22, (6), 9-28.

[29] Schmitz, H. and B. Musyck. Industrial Districts in Europe: Policy Lessons for Developing countries? World Development, (1994) 22, (6), 889-910.

[30] Schmitz, H. and K. Nadvi, Clustering and Industrialization: Introduction, World Development, (1999) 27, 1503-1514.

[31] Sotarauta M, Shared Leadership and Dynamic Capabilities in Regional Development (2005)

[32] Sagan, Halkier (ed.) Regionalism Contested: Institution, Society and Governance, Urban and Regional Planning and Development Series, Cornwall, Ashgate.

[33] Streeck W, Thelen K, Introduction: Institutional change in advanced political economies. Beyond Continuity: Institutional Change in Advanced Political Economies. (2005)

[34] Streeck, K Thelen (eds.), Oxford University Press, Oxford.

[35] Tether B S, Metcalfe J S, Systems of innovation in services in Sectoral Systems (2004)

[36] World Bank Pakistan: Devolution in Pakistan: Main Report - An Assessment \& Recommendations for Action. Poverty Reduction and Economic Management Sector Unit.

[37] South Asia Region, (2004) Vol. 1.

[38] World Bank, Pakistan - Growth and Export Competitiveness. WB: Poverty Reduction and Economic Management Sector Unit, South Asia Region. (2006a).

[39] World Bank, Transport competitiveness in Pakistan. WB: Energy and Infrastructure Operations Unit, South Asia Regions, Report No. 36523-PK (2006b) 